\title{
Multi-Antibiotic Resistance and Factors Affecting Carriage of Extended Spectrum $\beta$-Lactamase-Producing Enterobacteriaceae in Pediatric Population of Enugu Metropolis, Nigeria
}

\author{
Angus N. Oli ${ }^{1}{ }^{*}$, Vitalis I. Ogbuagu ${ }^{1}$, Chika P. Ejikeugwu ${ }^{2}$, Ifeanyichukwu R. Iroha ${ }^{2}$, \\ Malachy C. Ugwu ${ }^{1}$, Chijioke M. Ofomata ${ }^{3}$, Kenneth N. Okeke ${ }^{4}$, George O. Emechebe ${ }^{5}$, \\ Jude C. Okoro ${ }^{6}$, Chukwudi O. Okani ${ }^{7}$ and Stanley K. Onah ${ }^{4}$ \\ 1 Department of Pharmaceutical Microbiology and Biotechnology, Faculty of Pharmaceutical Sciences, \\ Nnamdi Azikiwe University, Awka, P.M.B 5025, Anambra State, Nigeria; vitalisogbuagu@yahoo.com (V.I.O.); \\ mc.ugwu@unizik.edu.ng (M.C.U.) \\ 2 Department of Applied Microbiology, Faculty of Science, Ebonyi State University, Abakaliki, P.M.B 053, \\ Ebonyi State, Nigeria; ejikeugwu_chika@yahoo.com (C.P.E.); iriroha@yahoo.com (I.R.I.) \\ 3 Department of Clinical Pharmacy and Pharmacy Management, Faculty of Pharmaceutical Sciences, Agulu, \\ Nnamdi Azikiwe University, Awka, P.M.B 5025, Anambra State, Nigeria; chijiokeofomata@gmail.com \\ 4 Department of Paediatrics, College of Health Sciences, Faculty of Medicine, Nnamdi Azikiwe University, \\ Nnewi Campus, Nnewi 435101, Anambra State, Nigeria: kenwados01@yahoo.co.uk (K.N.O.); \\ onahstan@gmail.com (S.K.O.) \\ 5 Department of Pediatrics, Faculty of Clinical Medicine, Chukwuemeka Odumegwu Ojukwu University, \\ Awka Campus, Awka 420108, Anambra State, Nigeria; nnabuike20g@yahoo.com \\ 6 Department of Paediatrics, Imo State University Teaching Hospital Orlu 473271, Imo State, Nigeria; \\ jubhildr@yahoo.com \\ 7 Department of Histopathology, Faculty of Clinical Medicine, Chukwuemeka Odumegwu Ojukwu \\ University Teaching Hospital Amaku, Awka, 420108, Anambra State, Nigeria; chukwudiokani@gmail.com \\ * Correspondence: a.n.oli@live.com
}

Received: 5 October 2019; Accepted: 6 November 2019; Published: 17 November 2019

Abstract: Extended-spectrum $\beta$-lactamase (ESBL)-producing organisms have become a serious challenge in healthcare delivery globally. The prevalence of ESBL carriage in healthy and sick children in Enugu, Nigeria, was bacteriologically investigated in this study. Four hundred and twenty-two biological samples (mid-stream urine and feces) were bacteriologically analyzed. The isolates were screened for ESBL production using Clinical and Laboratory Standards Institute (CLSI) breakpoints. The suspected ESBL producers were confirmed using double disc synergy test method. Out of the 162 isolates screened, $32(19.8 \%)$ were confirmed as ESBL positive, with a prevalence of $25.32 \%$ among sick children in Enugu State University Teaching Hospital (ESUTH), Parklane, Enugu and 13.89\% in apparently healthy children in a community setting. Klebsiella spp. and Escherichia coli had the highest prevalence of $34.6 \%$ and $28.6 \%$, respectively; Citrobacter spp. and Enterobacter spp. were $18.2 \%$ and $16.7 \%$, respectively. The ESBL positive isolates were resistant to sulfamethoxazole/trimethoprim $(100 \%)$, tetracycline $(100 \%)$, kanamycin $(96.9 \%)$, nitrofurantoin $(84.4 \%)$, ciprofloxacin $(68.6 \%)$, and chloramphenicol $(62.5 \%)$ but susceptible to meropenem (100\%), colistin (56.3\%), and gentamicin (50\%). Klebsiella spp. had the highest ESBL occurrence among sick children while E. coli had the highest ESBL occurrence among healthy children in Enugu. All ESBL-positive isolates were multiply resistant to conventional antibiotics. The emergence and spread of $\beta$-lactamase-producing Enterobacteriaceae in hospital and community environments highlight the possibility for an infection outbreak if not checked.

Keywords: ESBL; Enterobacteriaceae; gram-negative bacteria; antibiotic resistance; childhood infections 


\section{Introduction}

Antimicrobial resistance has been identified as one of the greatest threats to human health, and developing countries like Nigeria are worst hit by this crisis [1]. The major cause of this crisis is the indiscriminate and widespread use of antimicrobial agents [2], especially antibiotics containing a $\beta$-lactam ring, in prophylaxis and the treatment of bacterial diseases [3]. The misuse and abuse of $\beta$-lactam antibiotics has led to antibiotic selective pressure and the development of resistance to these drugs by most bacteria, particularly the Enterobacteriaceae, of which $\beta$-lactamase production remains the most important contributing factor to this resistance $[4,5]$. Extended-spectrum $\beta$-lactamases (ESBLs) have the extended ability to hydrolyze and cause resistance to various types of the newer $\beta$-lactam antibiotics, such as the expanded-spectrum cephalosporins and monobactams $[6,7]$. Some $\beta$-lactamases, like CTX-M and PER, are natural ESBLs, while other enzymes, such as TEM and SHV variants, acquire single or multiple amino acid substitutions/changes that extend their spectrum to cephalosporins $[6,8]$. The rapid emergence of ESBL-producing Enterobacteriaceae has drawn global attention because they are important causative agents of hospital infections typically associated with pneumonia, urinary tract infections, bacteremia, and other intra-abdominal infections $[9,10]$. The spread of these ESBLs has posed a threat to health, including hindering effective treatment, prolonged hospitalization, and increased treatment costs [10]. These have necessitated the need for extensive peer review research on ESBLs and increased awareness campaign on antimicrobial resistance, most especially in developing countries like Nigeria, where there is no or less surveillance activity and regulations guiding the use of antibiotics. In Nigeria, there are no previous studies and reports on the prevalence of ESBL-producing Enterobacteriaceae (ESBL-PE) in children. This study is imperative as it is poised to provide information on the prevalence of ESBL-PE in both healthy and sick children in Enugu Metropolis and highlights the resistance patterns of these organisms to non- $\beta$ lactam antibiotics. It also reveals possible risk factors to the spread of these organisms in hospital or community settings and highlights the best-practice infection control measures and appropriate choice of empirical antimicrobial coverage for ESBL infections in this population. This is critical for better defining the prevalence and characterization of risk factors to ESBL-producing Enterobacteriaceae in children, in order to adopt infection control best-practice measures and help in the appropriate choice of empirical antimicrobial coverage for ESBL infections in this population. This study therefore sought to bridge these gaps in knowledge.

\section{Materials and Methods}

\subsection{Patients}

A total of 422 clinical samples (mid-stream urine and feces) were collected and this comprised 233 samples from sick children from Enugu State University Teaching Hospital (ESUTH) and 105 samples from healthy school children in Abakpa and 84 samples from healthy school children in Emene, after permission had been sought for and obtained from the authorities of the schools and informed consent obtained from the guardians of these children. The study protocol was approved by the Ethical Committee of ESUTH (Approval number: ESUTHP/C-MAC/RA/034/177) and signed on 24 March 2017.

\subsection{Isolation}

The clinical specimens were inoculated on MacConkey agar plates and incubated at $37^{\circ} \mathrm{C}$ for $24 \mathrm{~h}$. Biochemical characterization of the isolates was achieved by subjecting them to biochemical tests for identification and differentiation of members of the Enterobacteriaceae according to the method of Tille [11].

\subsection{ESBL Screening Test}

ESBL screening test of the isolates were determined using the Kirby-Bauer disc diffusion method according to The Clinical \& Laboratory Standards Institute (CLSI) performance standards 
for antimicrobial disc susceptibility tests [12] using aztreonam (30 $\mu \mathrm{g})$, cefepime (30 $\mu \mathrm{g})$, cefotaxime $(30 \mu \mathrm{g})$, cefoxitin $(30 \mu \mathrm{g})$, ceftazidime $(30 \mu \mathrm{g})$, and ceftriaxone $(30 \mu \mathrm{g})$.

\subsection{Double Disc Synergy Test}

All isolates that were resistant to any of the $\beta$-lactam antibiotics were screened for ESBL production using the Double Disc Synergy Test (DDST). Suspensions of the isolates equivalent to 0.5 McFarland equivalent standards were streaked on the surface of a sterile Mueller Hinton agar plates, according to CLSI performance standards for antimicrobial disc susceptibility tests [12]. After $25 \mathrm{~min}$ of pre-incubation, combination discs of $20 \mu \mathrm{g}$ amoxicillin/10 $\mu \mathrm{g}$ clavulanic acid (Oxoid, Wade Road, Basingstoke, Hampshire, RG24 8PW, UK) were be placed at the center of the plates and $30 \mu \mathrm{g}$ ceftazidime $/ 30 \mu \mathrm{g}$ cefotaxime discs (Oxoid, UK) were placed $15 \mathrm{~mm}$ apart from the center discs and incubated at $37^{\circ} \mathrm{C}$ for $18 \mathrm{~h}$. The isolates, whose zone around the test antibiotic discs increased towards the center disc (amoxicillin $20 \mu \mathrm{g} /$ clavulanic acid $10 \mu \mathrm{g}$ ), were considered to be positive for ESBL production.

\subsection{Susceptibility Test of Isolates to Non- $\beta$-Lactam Antibiotics}

The susceptibility of the ESBL positive isolates to non- $\beta$ lactam antibiotics from different classes of antibiotics were determined using the Kirby-Bauer disc diffusion method, according to CLSI performance standards for antimicrobial disc susceptibility tests [12]. The isolates were challenged with the following different classes of antibiotics (Oxoid, UK): amikacin (30 $\mu \mathrm{g})$, chloramphenicol $(30 \mu \mathrm{g})$, ciprofloxacin $(5 \mu \mathrm{g})$, colistin sulfate $(25 \mu \mathrm{g})$, gentamicin $(30 \mu \mathrm{g})$, kanamycin $(5 \mu \mathrm{g})$, meropenem $(10 \mu \mathrm{g})$, nitrofurantoin $(300 \mu \mathrm{g})$, tetracycline $(30 \mu \mathrm{g})$, and sulfamethoxazole/trimethoprim $(25 \mu \mathrm{g})$. Their inhibitory zone diameters were interpreted as susceptible (S), intermediate (I), or resistant (R), according to the zone diameter breakpoints of the performance standards of antibiotic susceptibility testing of CLSI [12].

\subsection{Multiple Antibiotic Resistance Index}

The multiple antibiotic resistance index is calculated as the ratio of the number of antibiotics to which the isolates were resistant to the total number of antibiotics against which the isolates were tested $(\mathrm{a} / \mathrm{b})$. Multiple antibiotic resistance index (MARI) values greater than $0.2(20 \%)$ were considered a high-risk source of contamination where antibiotics are often used, as described in previous reports $[13,14]$.

\subsection{Statistical Data Analysis}

Data analysis was conducted using GraphPad Prism version 5.00 for Windows (GraphPad Software, Inc., San Diego, CA, USA). Descriptive data analysis of the characteristics of the study participant was conducted to evaluate the characteristics of the study participants in relation to ESBL-PE carriage rate or colonization frequency. Chi-square test was used to describe the carriage of Enterobacteriaceae in the urine and fecal samples of the children in the hospital and community setting and in highlighting possible risk factors.

\section{Results}

A total of 422 biological samples were collected out of which 233 (55.21\%) came from ESUTH (hospital environment) while 189 (44.79\%) came from community (Table 1). 
Table 1. The distribution of samples used for this study.

\begin{tabular}{ccccc}
\hline \multirow{2}{*}{ Setting } & \multirow{2}{*}{ Location } & \multicolumn{3}{c}{ Number of Specimen Used } \\
\cline { 3 - 4 } & & Urine, $\boldsymbol{N}(\mathbf{\%})$ & Feces, $\boldsymbol{N}$ (\%) & Total, $\boldsymbol{N}(\%)$ \\
\hline \multirow{2}{*}{ Hospital } & ESUTH (sick children) & $128(30 \%)$ & $105(25 \%)$ & $233(55 \%)$ \\
Community & Abakpa (apparently healthy children) & $58(14 \%)$ & $47(11 \%)$ & $105(25 \%)$ \\
& Emene (apparently healthy children) & $46(11 \%)$ & $38(9 \%)$ & $84(20 \%)$ \\
\hline
\end{tabular}

Note: ESUTH = Enugu State University Teaching Hospital.

Of the 233 samples from ESUTH, 79 (33.91\%) were positive for Enterobacteriaceae in the hospital while out of the 189 samples from community setting, 108 (57.14\%) had Enterobacteriaceae carriage either in their urine of feces (Table 2).

Table 2. Extended-spectrum $\beta$-lactamase (ESBL) confirmatory testing of the Enterobacteriaceae isolates.

\begin{tabular}{|c|c|c|c|c|c|c|}
\hline \multirow{2}{*}{ Enterobacteriaceae Isolates } & \multicolumn{3}{|c|}{ ESUTH (Hospital Setting) } & \multicolumn{3}{|c|}{ Abakpa/Emene (Community Setting) } \\
\hline & $\begin{array}{l}\text { Positive for } \\
\text { ESBL }\end{array}$ & $\begin{array}{c}\text { Negative for } \\
\text { ESBL }\end{array}$ & Total & $\begin{array}{l}\text { Positive for } \\
\text { ESBL }\end{array}$ & $\begin{array}{l}\text { Negative for } \\
\text { ESBL }\end{array}$ & Total \\
\hline Citrobacter spp. & 2 & 9 & 11 & 0 & 12 & 12 \\
\hline Enterobacter spp. & 1 & 5 & 6 & 0 & 4 & 4 \\
\hline Escherichia coli & 8 & 20 & 28 & 8 & 28 & 36 \\
\hline Klebsiella spp. & 9 & 15 & 24 & 4 & 17 & 21 \\
\hline Proteus spp. & 0 & 7 & 7 & 0 & 7 & 7 \\
\hline Serratia spp. & 0 & 3 & 3 & 3 & 25 & 28 \\
\hline Total & 20 & 59 & 79 & 15 & 93 & 108 \\
\hline
\end{tabular}

Note: ESBL $=$ Extended-spectrum $\beta$-lactamase.

From Table 2 also, the chi-square test for carriage of Enterobacteriaceae in the urine and fecal samples of the children in the hospital and community setting revealed a significant difference, with a $p$-value of 0.0033 and chi-square, degrees of freedom $(\mathrm{df})=17.73,5$. With a total of 79 Enterobacteriaceae isolates in a hospital setting, the prevalence of ESBL-producing Enterobacteriaceae isolates was 25.32\%, while in the community setting, the prevalence was much lower $(13.89 \%)$. The chi-square test for trend (chi-square, $\mathrm{df}=0.02790,1)$ showed that there were equal chances of occurrence of ESBL and non-ESBL isolates in the hospital $(p=0.8674)$. The same was also true in community setting (chi-square, $\mathrm{df}=0.003946,1$ and $p=0.9499)$. The chi-square for trend for ESBL positivity in Hospital versus Community (chi-square, $\mathrm{df}=3.273,1)$ showed no significant difference $(p=0.0704)$. This implies that the trend of ESBL-producing Enterobacteriaceae is equal in both settings.

In ESUTH, a total of 233 sick children participated in the study (Table 3), of which 114 were males and 119 were females. As many as 20 children representing 8.58\% were ESBL-PE carriers. Males had a higher ESBL-PE colonization frequency than females, although this was not significantly different $(p>0.05)$. Chi-square analysis of the risk factors associated with Enterobacteriaceae carriage among the sick children in ESUTH showed that of all the possible risk factors/covariates considered, the source of drinking water and non-practice of regular hand washing were the only factors associated with the infection with $p<0.0001$ and $p=0.0067$, respectively. Considering ESBL-PE carriage no risk factors were found.

In the community setting (Table 4), the risk factors associated with Enterobacteriaceae carriage included stage in school (daycare, nursery, and primary) with $p=0.0128$, source of drinking water with $p=0.0001$, and school type (public versus private schools) with $p=0.0004$. The risk factors for ESBL-PE carriage were indeterminate. The bivariate analyses of the covariates in Enterobacteriaceae and ESBL-PE carriage in sick and healthy children revealed no significant risk. 
Table 3. Survey of risk factors associated with ESBL-producing Enterobacteriaceae (ESBL-PE) carriage in sick children in ESUTH.

\begin{tabular}{|c|c|c|c|c|c|c|c|}
\hline \multirow{3}{*}{\multicolumn{2}{|c|}{$\begin{array}{c}\text { Covariates (ESBL-NPE }=\text { ESBL Non-Producing } \\
\text { Enterobacteriaceae) }\end{array}$}} & \multicolumn{6}{|c|}{ Prevalence } \\
\hline & & \multirow{2}{*}{$\begin{array}{c}\text { Total Sampled } \\
\text { N (\%) } \\
233(100 \%) \\
\end{array}$} & \multirow{2}{*}{$\begin{array}{c}\text { Enterobacteriaceae } \\
\text { Positive } N(\%) \\
81(34.76)\end{array}$} & \multirow{2}{*}{$\begin{array}{c}\text { Enterobacteriaceae } \\
\text { Negative } N(\%) \\
152(65.24)\end{array}$} & \multirow{2}{*}{$\begin{array}{l}\text { ESBL-PE } \\
N(\%) \\
20(8.58)\end{array}$} & \multirow{2}{*}{$\begin{array}{c}\text { ESBL-NPE } \\
N(\%) \\
61(26.18)\end{array}$} & \multirow{2}{*}{$\begin{array}{c}\text { ESBL-PE } \\
\text { Colonization } \\
\text { Frequency \% }\end{array}$} \\
\hline & & & & & & & \\
\hline \multirow{3}{*}{ Age (years) } & $0-5$ & $101(43.35)$ & $34(33.66)$ & $67(66.34)$ & $6(5.94)$ & $28(27.72)$ & $17.6 \%(6 / 34)$ \\
\hline & $6-10$ & 88 (37.77) & $28(31.82)$ & $60(68.18)$ & $10(11.36)$ & $18(20.45)$ & $35.7 \%(10 / 28)$ \\
\hline & $11-15$ & $44(18.88)$ & $19(43.18)$ & $25(56.82)$ & $4(9.09)$ & $15(34.09)$ & $21.1 \%(4 / 19)$ \\
\hline \multirow{2}{*}{ Gender } & Male & 114 (48.93) & 39 (34.21) & 75 (65.79) & $11(9.65)$ & $28(24.56)$ & $28.2 \%(11 / 39)$ \\
\hline & Female & $119(51.07)$ & $42(35.29)$ & $77(64.71)$ & $9(7.56)$ & $33(27.73)$ & $21.4 \%(9 / 42)$ \\
\hline Type of school & Public & $97(41.63)$ & $51(52.58)$ & $46(47.42)$ & $15(15.46)$ & $37(38.144)$ & $29.4 \%(15 / 51)$ \\
\hline \multirow{3}{*}{ Stage in school } & Daycare & 35 (15.02) & $15(42.86)$ & $20(57.14)$ & $2(5.71)$ & $13(37.14)$ & $13.3 \%(2 / 15)$ \\
\hline & Nursery & $68(29.18)$ & $40(58.82)$ & $28(41.18)$ & $10(14.71)$ & $30(44.12)$ & $25 \%(10 / 40)$ \\
\hline & Primary & $130(55.79)$ & $26(20.00)$ & $104(80.00)$ & $8(6.15)$ & $18(13.85)$ & $30.8 \%(8 / 26)$ \\
\hline \multirow{3}{*}{$\begin{array}{l}\text { Who normally prescribed } \\
\text { antibiotics given to the child? }\end{array}$} & Doctors & $63(27.03)$ & $22(34.92)$ & $41(65.08)$ & $3(4.76)$ & $19(30.16)$ & $13.6 \%(3 / 22)$ \\
\hline & Pharmacists & 25 (10.73) & $12(48.00)$ & $13(52.00)$ & $1(4.00)$ & $11(44.00)$ & $8.3 \%(1 / 12)$ \\
\hline & PPMD* & $145(62.23)$ & $47(32.41)$ & $98(67.59)$ & $16(11.03)$ & $31(21.38)$ & $38.1 \%(16 / 42)$ \\
\hline $\begin{array}{l}\text { Hospital admission in the last } \\
3-6 \text { months }\end{array}$ & Yes & $77(33.04)$ & $33(42.86)$ & $44(57.14)$ & $15(19.48)$ & $18(23.38)$ & $45.5 \%(15 / 33)$ \\
\hline \multirow{2}{*}{ Share public toilet at home } & Yes & $48(20.60)$ & $21(43.75)$ & $27(56.25)$ & $3(6.25)$ & $18(37.50)$ & $31.4 \%(11 / 35)$ \\
\hline & No & $36(15.45)$ & $6(16.67)$ & $30(83.33)$ & $0(0.00)$ & $6(16.67)$ & $19.7 \%(9 / 46)$ \\
\hline \multirow{2}{*}{$\begin{array}{l}\text { Practice of regular hand } \\
\text { washing }\end{array}$} & Yes & $85(36.48)$ & $20(23.53)$ & 65 (76.47) & $3(3.53)$ & $17(20.00)$ & $15 \%(3 / 20)$ \\
\hline & No & $148(63.52)$ & $61(41.22)$ & 87 (58.78) & $17(11.49)$ & 43 (29.05) & $27.9 \%(17 / 61)$ \\
\hline \multirow{4}{*}{$\begin{array}{c}\text { Source of water supply at } \\
\text { home }\end{array}$} & Tap & $84(86.05)$ & $9(10.71)$ & 75 (89.29) & $1(1.19)$ & $8(9.52)$ & $11.1 \%(1 / 9)$ \\
\hline & Well & $117(50.21)$ & $53(45.30)$ & $64(54.70)$ & $16(13.68)$ & $37(31.62)$ & $30.2 \%(16 / 53)$ \\
\hline & Bore-hole & 32 (13.73) & 19 (59.38) & $13(40.63)$ & $3(9.38)$ & $16(50.00)$ & $15.8 \%(3 / 19)$ \\
\hline & River & $0(0.00)$ & $0(0.00)$ & $0(0.00)$ & $0(0.00)$ & $0(0.00)$ & $0.0 \%$ \\
\hline \multirow{3}{*}{ Type of nutrition } & Breast milk & $29(12.45)$ & $8(27.59)$ & $21(72.41)$ & $0(0.00)$ & $8(27.59)$ & $0.0 \%$ \\
\hline & Dairy food & $37(15.88)$ & $19(51.35)$ & $18(48.65)$ & 7 (18.92) & $12(32.43)$ & $36.8 \%(7 / 19)$ \\
\hline & Household food & 167 (71.67) & $54(32.34)$ & $113(67.66)$ & $13(7.78)$ & $41(24.55)$ & $24.1 \%(13 / 54)$ \\
\hline
\end{tabular}

health care pharmaceutical and medical products to the are also called private patent medicine ve 
Table 4. Survey of risk factors associated with ESBL-PE carriage among the apparently healthy children.

\begin{tabular}{|c|c|c|c|c|c|c|c|}
\hline \multirow{2}{*}{\multicolumn{2}{|c|}{$\begin{array}{c}\text { Covariates [ESBL-NPE }=\text { ESBL Non-Producing } \\
\text { Enterobacteriaceae }]\end{array}$}} & \multicolumn{6}{|c|}{ Prevalence } \\
\hline & & \multirow{2}{*}{$\begin{array}{c}\text { Total Sampled } \\
N(\%) \mathbf{1 8 9}(\mathbf{1 0 0 \% )} \\
51(26.98)\end{array}$} & \multirow{2}{*}{$\begin{array}{c}\text { Enterobacteriaceae } \\
\text { Positive } N(\%) 81 \\
\quad(42.86) \\
28(54.90)\end{array}$} & \multirow{2}{*}{$\begin{array}{c}\text { Enterobacteriaceae } \\
\text { Negative N (\%) } \\
\mathbf{1 0 8}(\mathbf{5 7 . 1 4 )} \\
23(45.10)\end{array}$} & \multirow{2}{*}{$\begin{array}{c}\text { ESBL-PE } \\
N(\%) 12(6.34) \\
3(10.71)\end{array}$} & \multirow{2}{*}{$\begin{array}{c}\text { ESBL-NPE } \\
N \text { (\%) } 69(75.31) \\
25(89.29)\end{array}$} & \multirow{2}{*}{$\begin{array}{c}\begin{array}{c}\text { ESBL-PE } \\
\text { Colonization } \\
\text { Frequency } \\
(\mathbf{6 . 8 8 \% )}\end{array} \\
5.88\end{array}$} \\
\hline \multirow{3}{*}{ Age (years) } & $0-5$ & & & & & & \\
\hline & $6-10$ & $102(53.96)$ & 39 (20.63) & $63(61.76)$ & $7(17.95)$ & $32(82.05)$ & 6.86 \\
\hline & $11-15$ & $36(19.05)$ & $14(7.41)$ & $22(61.11)$ & $2(14.29)$ & $12(85.71)$ & 5.56 \\
\hline \multirow{2}{*}{ Gender } & Male & $81(42.86)$ & $38(20.11)$ & 43 (53.09) & 7 (18.42) & $31(81.58)$ & 8.64 \\
\hline & Female & $108(57.14)$ & $43(22.75)$ & $65(60.19)$ & 5 (11.63) & 38 (88.37) & 4.63 \\
\hline \multirow{2}{*}{ Type of school } & Private & $99(52.38)$ & $30(15.87)$ & $69(69.70)$ & $3(10.00)$ & $27(90.00)$ & 3.03 \\
\hline & Public & $90(47.62)$ & $51(26.98)$ & 39 (43.33) & $9(17.65)$ & $42(82.35)$ & 10.00 \\
\hline \multirow{3}{*}{ Stage in school } & Daycare & 34 (17.99) & $7(3.70)$ & $27(79.41)$ & $0(0.00)$ & $7(100.00)$ & 0.00 \\
\hline & Nursery & $51(26.98)$ & $26(13.76)$ & $25(49.02)$ & $3(11.54)$ & $23(88.46)$ & 5.88 \\
\hline & Primary & $104(55.03)$ & $48(25.40)$ & $56(53.85)$ & $9(18.75)$ & 39 (81.25) & 8.65 \\
\hline \multirow{3}{*}{$\begin{array}{l}\text { Who normally prescribed } \\
\text { antibiotics given to the child? }\end{array}$} & Doctors & $30(15.87)$ & $5(2.65)$ & $25(83.33)$ & $0(0.00)$ & $5(100.00)$ & 0.00 \\
\hline & Pharmacists & $14(7.41)$ & $3(1.59)$ & $11(78.57)$ & $0(0.00)$ & $3(100.00)$ & 0.00 \\
\hline & PPMD & 145 (76.72) & $73(38.64)$ & $72(49.66)$ & $12(16.44)$ & $61(84.62)$ & 8.28 \\
\hline \multirow{2}{*}{$\begin{array}{l}\text { Hospital admission in the last 3-6 } \\
\text { months }\end{array}$} & Yes & $36(19.05)$ & $13(6.89)$ & $23(63.89)$ & $1(7.69)$ & $11(84.62)$ & 2.78 \\
\hline & No & 153 (80.95) & $68(35.98)$ & 85 (55.56) & $11(16.18)$ & $57(83.82)$ & 7.19 \\
\hline \multirow{2}{*}{ Share public toilet at home } & Yes & 89 (47.09) & $50(26.46)$ & $39(43.82)$ & $9(18.00)$ & $41(82.00)$ & 10.11 \\
\hline & No & $100(52.91)$ & $31(16.40)$ & $69(69.00)$ & $3(9.68)$ & $28(90.32)$ & 3.00 \\
\hline \multirow{2}{*}{ Practice of regular hand washing } & Yes & $48(25.40)$ & $12(6.35)$ & $36(75.00)$ & $1(8.33)$ & $11(91.67)$ & 2.08 \\
\hline & No & $141(74.60)$ & $69(36.51)$ & $72(51.06)$ & $11(15.94)$ & $58(84.06)$ & 7.80 \\
\hline \multirow{4}{*}{ Source of water supply at home } & Tap & $27(14.29)$ & $2(1.06)$ & $25(92.59)$ & $0(0.00)$ & $2(100.00)$ & 0.00 \\
\hline & Well & $142(75.13)$ & $72(38.10)$ & $70(49.30)$ & $12(16.67)$ & $60(83.33)$ & 8.45 \\
\hline & Bore-hole & $20(10.58)$ & $7(3.70)$ & $13(65.00)$ & $0(0.00)$ & $7(100.00)$ & 0.00 \\
\hline & River & $0(0.00)$ & $0(0.00)$ & $0(0.00)$ & $0(0.00)$ & $0(0.00)$ & 0.00 \\
\hline \multirow{3}{*}{ Type of nutrition } & Breast milk & $0(0.00)$ & $0(0.00)$ & $0(0.00)$ & $0(0.00)$ & $0(0.00)$ & 0.00 \\
\hline & Dairy food & 24 (12.70) & $5(2.65)$ & 19 (79.17) & $2(40.00)$ & $3(60.00)$ & 8.33 \\
\hline & Household food & $165(87.30)$ & $76(40.21)$ & $89(53.94)$ & $10(13.16)$ & $66(86.84)$ & 6.06 \\
\hline
\end{tabular}


The ESBL-producing Enterobacteriaceae (ESBL-PE) isolates showed high resistance (Table 5) to tetracycline, co-trimoxazole, nitrofurantoin, and kanamycin. However, they showed average susceptibility to colistin and gentamicin. The $100 \%$ susceptibility of the ESBL-PE isolates to meropenem was noted in this study. Two-way ANOVA of the isolate susceptibilities to the used drugs showed that they were significantly resistant $(p=0.0163)$. Also, all the ESBL-PE isolates had a MARI greater than $0.2(20 \%)$ giving an incidence of multi-antibiotic resistance strains of $100 \%$ (Table 6).

Table 5. Overall antibiogram of all the ESBL-PE isolates.

\begin{tabular}{ccccc}
\hline Antibiotics & Susceptible & $\begin{array}{c}\text { Intermediate } \\
\text { Susceptible }\end{array}$ & Resistant & Total \\
\hline Meropenem $(10 \mu \mathrm{g})$ & 32 & 0 & 0 & 32 \\
Amikacin $(30 \mu \mathrm{g})$ & 11 & 19 & 2 & 32 \\
Colistin Sulfate $(25 \mu \mathrm{g})$ & 18 & 0 & 14 & 32 \\
Gentamicin $(30 \mu \mathrm{g})$ & 16 & 1 & 15 & 32 \\
Chloramphenicol $(30 \mu \mathrm{g})$ & 10 & 2 & 20 & 32 \\
Ciprofloxacin $(5 \mu \mathrm{g})$ & 7 & 3 & 22 & 32 \\
Nitrofurantoin $(300 \mu \mathrm{g})$ & 5 & 0 & 27 & 32 \\
Kanamycin $(5 \mu \mathrm{g})$ & 0 & 1 & 32 & 32 \\
Tetracycline $(30 \mu \mathrm{g})$ & 0 & 0 & 32 & 32 \\
Co-trimoxazole $(25 \mu \mathrm{g})$ & 0 & 0 & & \\
\hline
\end{tabular}

Table 6. Overall multi-antibiotic resistance index (MARI) of all the ESBL-producing Enterobacteriaceae (ESBL-PE) isolates.

\begin{tabular}{|c|c|c|c|c|c|c|}
\hline Setting & \multicolumn{3}{|c|}{ From Sick Children } & \multicolumn{3}{|c|}{ From Healthy Children } \\
\hline $\begin{array}{l}\text { Isolates } \\
\text { Number }\end{array}$ & $\begin{array}{c}\text { Number of } \\
\text { Antibiotics } \\
\text { Isolates Were } \\
\text { Resistant to (a) }\end{array}$ & MARI (a/b) & $\%$ MARI & $\begin{array}{l}\text { Number of } \\
\text { Antibiotics } \\
\text { Isolates Were } \\
\text { Resistant to }\end{array}$ & MARI (a/b) & $\%$ MARI \\
\hline \multicolumn{7}{|c|}{ Citrobacter spp. $(n=2)$} \\
\hline 1 & 7 & 0.70 & 70 & & & \\
\hline 2 & 6 & 0.60 & 60 & & & \\
\hline \multicolumn{7}{|c|}{ Enterobacter spp. $(n=1)$} \\
\hline 1 & 5 & 0.5 & 50 & \multirow{2}{*}{\multicolumn{3}{|c|}{ Escherichia coli $(n=8)$}} \\
\hline \multicolumn{2}{|c|}{ Escherichia coli $(n=8)$} & & & & & \\
\hline 1 & 7 & 0.70 & 70 & 4 & 0.40 & 40 \\
\hline 2 & 7 & 0.70 & 70 & 5 & 0.50 & 50 \\
\hline 3 & 3 & 0.30 & 30 & 6 & 0.60 & 60 \\
\hline 4 & 8 & 0.80 & 80 & 4 & 0.40 & 40 \\
\hline 5 & 7 & 0.70 & 70 & 7 & 0.70 & 70 \\
\hline 6 & 6 & 0.60 & 60 & 6 & 0.60 & 60 \\
\hline 7 & 6 & 0.60 & 60 & 7 & 0.70 & 70 \\
\hline 8 & 5 & 0.50 & 50 & 7 & 0.70 & 70 \\
\hline \multicolumn{2}{|c|}{ Klebsiella spp. $(n=9)$} & & & \multicolumn{3}{|c|}{ Klebsiella spp. $(n=4)$} \\
\hline 1 & 8 & 0.80 & 80 & 5 & 0.50 & 50 \\
\hline 2 & 6 & 0.60 & 60 & 6 & 0.60 & 60 \\
\hline 3 & 6 & 0.60 & 60 & 7 & 0.70 & 70 \\
\hline 4 & 7 & 0.70 & 70 & 5 & 0.50 & 50 \\
\hline 5 & 8 & 0.80 & 80 & & & \\
\hline 6 & 4 & 0.40 & 40 & & & \\
\hline 7 & 7 & 0.70 & 70 & & & \\
\hline 8 & 6 & 0.60 & 60 & & & \\
\hline 9 & 6 & 0.60 & 60 & & & \\
\hline
\end{tabular}

Note: (a) = Number of Antibiotics Isolates were Resistant to while $(b)=$ Total Number of Antibiotics Used/tested = 10.

\section{Discussion}

Several studies have demonstrated the prevalence of ESBL-producing Enterobacteriaceae in many parts of the world [15,16], and a number of individual reports are available in Nigeria [17-19]. 
This study was undertaken to bridge the gap on the paucity of data on the prevalence of ESBL-producing Enterobacteriaceae in a purely pediatric population in this part of the world. The overall prevalence of ESBL-PE among sick children in ESUTH was 8.58\%, whereas in healthy children, it was $6.34 \%$. This shows that the ESBL-PE carriage rate was slightly higher among the sick children compared to the healthy children, and this may be as a result of higher prevalence and dissemination of ESBL pathogens in hospital settings as reported in various studies $[17,20,21]$. The overall ESBL-PE prevalence of $6.34 \%$ among healthy children in community setting is lower than what was reported in healthy community Tanzanian (11.2\%) and Libyan children 13.4\% [22,23]. However, our report showed a higher than prevalence in healthy Portuguese (2.7\%), Swedish (2.9\%), French $(4.6 \%)$ children [24]. Our report also showed much lower prevalence than that of $23 \%$ in Lao preschool children, $24.8 \%$ in healthy Lebanese children, and 59\% in healthy Banguian children, Central African Republic [25-27]. The observed $8.58 \%$ prevalence of ESBL-PE among sick children in ESUTH is much lower when compared to the prevalence of 31\% found in hospitalized children in Niger and 32.6\% recorded in Guinea-Bissau [28,29]. Out of all the ESBL-PE isolates from sick children in ESUTH, Klebsiella spp. and Escherichia coli had the highest prevalence of $34.6 \%$ and $28.6 \%$ respectively, compared to Citrobacter spp. with $18.2 \%$ and Enterobacter spp. with $16.7 \%$. Although, it has been said to be difficult to make valid comparison of the prevalence of ESBLs because of the variation in study design [30], the findings from this study are comparable to the work of Yahaya et al. [31], which recorded an ESBL prevalence of $23.8 \%$ and $30 \%$ for E. coli and Klebsiella spp., respectively, among sick individuals in Maiduguri Teaching Hospital, Nigeria. Previous studies from Nigeria, although not specifically focused on children, have reported ESBL production in Klebsiella spp., E. coli, Enterobacter spp., and Citrobacter spp. from hospital settings and from 2003 to 2017, the rate varied from 6\% to 87\% [17,32-34]. The high ESBL prevalence detected in Klebsiella spp. compared to Escherichia coli is in agreement with the findings of some of these studies in Nigeria. The reason for high ESBL prevalence in Klebsiella spp. could be connected with the fact that Klebsiella spp. tend to be more associated with nosocomial infections than E. coli, hence it has more chance to acquire multidrug resistance plasmids and disseminate more in the hospital settings $[35,36]$. Our findings showed that all the ESBL-PE isolates were resistant to multiple antibiotics, suggesting an incidence of multi-antibiotic resistance strains of $100 \%$. This points to poor compliance to antibiotic policy, high use or misuse of antibiotics, high rate of transfer of multi-drug resistant plasmids from species to species, clonal dissemination of ESBL-PE from patients to patients in the hospital settings and to healthy individuals in the community (that serve as reservoirs of these pathogens) and emerging of new strains of community-acquired ESBL-producing Enterobacteriaceae. Our study showed that colistin resistance was as high as $43.75 \%$, contrary to known resistance rates to polymyxins, which are generally between $10 \%$ and $23 \%[37,38]$. Colistin-resistant organisms had been postulated to spread from animals to human [39-42], suggesting the concept of one health. Observational studies have shown that polymyxins are used profusely in animal feed in the community to enhance growth. The observed high resistance to colistin in our study calls for caution and regulation in such unlicensed/off-label use of antibiotics. Colistin resistance among ESBL-producing Enterobacteriaceae is becoming a public health concern and is postulated to be due to the plasmid-borne $m c r-1$ gene $[38,42,43]$.

Therefore, for effective treatment of ESBL infections, empirical antibiotic regimens should be selected based on individual antibiogram. There is need for a multifactional approach combining continued research, prudent use of antibiotics, effective ESBL infections control measures and rapid detection of ESBL-producing organisms in routine clinical laboratory in order to contain the emergence and spread of ESBL-producing Enterobacteriaceae in the human population.

The source of drinking water, non-practice of regular hand washing, the stage in school (daycare, nursery, and primary), and school type (public versus private schools) were the common factors associated with Enterobacteriaceae infections in this study. Previous studies [44,45] have observed that demographic variables and comorbid conditions predisposed patients to carbapenemase-producing Enterobacteriaceae infections. Also, clean water has been claimed to be the most important public health intervention strategy, followed by vaccination, in promoting both individual and global health $[46,47]$. 
This study therefore calls for the need to control infectious diseases through the regular and timely provision of clean drinking water. Also important in infection control is the continuous and consistent adoption of hygienic practices [48] and mass education through all available public and social media as well as regular hand washing.

\section{Conclusions}

The prevalence of ESBL-producing bacteria was higher in sick children compared to healthy children in Enugu. Klebsiella spp. had the highest ESBL occurrence among sick children while E. coli had the highest ESBL occurrence among healthy children in Enugu. All the ESBL positive isolates were multiply resistant to conventional antibiotics. Meropenem proved to be the drug of choice in the management of infections caused by isolates in both community and hospital settings.

Author Contributions: A.N.O. and I.R.I.: conceptualization and design; V.I.O.: investigations; C.P.E.: writing—original draft preparation; A.N.O.: writing—original draft preparation and data analysis; M.C.U., C.O.O. and S.K.O.: writing—review and editing; K.N.O.: Data curation; G.O.E., C.M.O. and J.C.O.: literature search

Funding: This research received no external funding

Acknowledgments: Authors hereby acknowledge the various supports given the authorities of the schools from where the children were recruited, the guardians of these children and the management of ESUTH. We also wish to express gratitude to the peer reviewers that concertedly assisted in improving the final quality of this manuscript.

Conflicts of Interest: The authors declare no conflict of interest.

\section{References}

1. World Health Organization (WHO). Antimicrobial Resistance Global Report on Surveillance; WHO: Geneva, Switzerland, 2014. Available online: http://www.who.int/drugresistance/documents/surveillance/port/en/ (accessed on 15 May 2017).

2. Ujam, N.T.; Oli, A.N.; Ikegbunam, M.N.; Adikwu, M.U.; Esimone, C.O. Antimicrobial Resistance Evaluation of Organisms Isolated from Liquid Herbal Products Manufactured and Marketed in South Eastern Nigeria. Br. J. Pharm. Res. 2013, 3, 548-562. [CrossRef]

3. Ejiofor, O.S.; Ajunwa, O.M.; Ezeudu, C.E.; Emechebe, G.O.; Okeke, K.N.; Ifezulike, C.C.; Ekejindu, I.M.; Okoye, J.N.; Osuala, E.O.; Oli, A.N. The Bacteriology and Its Virulence Factors in Neonatal Infections: Threats to Child Survival Strategies. J. Pathog. 2018, 2018, 4801247. [CrossRef] [PubMed]

4. Fair, R.J.; Tor, Y. Antibiotics and bacterial resistance in the 21st century. Perspect. Med. Chem. 2014, 6, 25-64. [CrossRef] [PubMed]

5. Li, B.; Webster, T.J. Bacteria antibiotic resistance: New challenges and opportunities for implant-associated orthopedic infections. J. Orthop. Res. 2018, 36, 22-32. [CrossRef] [PubMed]

6. Rawat, D.; Nair, D. Extended-spectrum $\beta$-lactamases in Gram Negative Bacteria. J. Glob. Infect. Dis. 2010, 2, 263-274. [CrossRef]

7. Shaikh, S.; Fatima, J.; Shakil, S.; Rizvi, S.M.; Kamal, M.A. Antibiotic resistance and extended spectrum $\beta$-lactamases: Types, epidemiology and treatment. Saudi J. Biol. Sci. 2015, 22, 90-101. [CrossRef]

8. Liakopoulos, A.; Mevius, D.; Ceccarelli, D. A Review of SHV Extended-Spectrum $\beta$-Lactamases: Neglected Yet Ubiquitous. Front. Microbiol. 2016, 7, 1374. [CrossRef]

9. Pana, Z.D.; Zaoutis, T. Treatment of extended-spectrum $\beta$-lactamase-producing Enterobacteriaceae (ESBLs) infections: What have we learned until now? F1000Research 2018, 7. [CrossRef]

10. Lee, D.S.; Lee, S.J.; Choe, H.S. Community-Acquired Urinary Tract Infection by Escherichia coli in the Era of Antibiotic Resistance. BioMed Res. Int. 2018, 2018, 7656752. [CrossRef]

11. Tille, P.M. Traditional cultivation and identification. In Bailey and Scott's Diagnostic Microbiology, 13th ed.; Mosby, Inc.: St. Louis, MO, USA, 2014; pp. 83-89.

12. Clinical and Laboratory Standards Institute (CLSI). Performance Standards for Antimicrobial Disk Susceptibility Tests, 12th ed.; Informational Supplement (M02-A12); Clinical and Laboratory Standards Institute: Wayne, PA, USA, 2017. 
13. Osundiya, O.O.; Oladele, R.O.; Oduyebo, O.O. Multiple antibiotic resistance (MAR) indices of Pseudomonas and Klebsiella species isolates in Lagos university teaching hospital. Afr. J. Exp. Microbiol. 2013, 14, 164-168. [CrossRef]

14. Oli, A.N.; Iyinagolu, R.A.; Ichoku, U.J.; Ugwu, M.C.; Ezeobi, I.; Ejiofor, O.S.; Anagu, L.O.; Esimone, C.O. Antibiotic susceptibility profile of community isolates of Staphylococcus aureus. J. Pharm. Res. Opin. 2013, 3, $42-47$.

15. Abrar, S.; Hussain, S.; Khan, R.A.; Ul Ain, N.; Haider, H.; Riaz, S. Prevalence of extended-spectrum- $\beta$-lactamase-producing Enterobacteriaceae: First systematic meta-analysis report from Pakistan. Antimicrob. Resist. Infect. Control 2018, 7, 26. [CrossRef] [PubMed]

16. Díaz-Agero Pérez, C.; López-Fresneña, N.; Rincon Carlavilla, A.L.; Hernandez Garcia, M.; Ruiz-Garbajosa, P.; Aranaz-Andrés, J.M.; Canton, R. Local prevalence of extended-spectrum $\beta$-lactamase (ESBL) producing Enterobacteriaceae intestinal carriers at admission and co-expression of ESBL and OXA-48 carbapenemase in Klebsiella pneumoniae: A prevalence survey in a Spanish University Hospital. BMJ Open 2019, 9, e024879. [CrossRef] [PubMed]

17. Iroha, I.R.; Adikwu, M.U.; Amadi, E.S.; Aibinu, I.E.; Esimone, C.O. Characterization of extended spectrum $\beta$-lactamase producing E. coli from secondary and tertiary hospital in South Eastern Nigeria. Res. J. Microbiol. 2008, 3, 514-519. [CrossRef]

18. Olowe, O.A.; Aboderin, B.W. Detection of extended-spectrum $\beta$-lactamase producing strains of Escherichia coli and Klebsiella sp. in atertiary Health centre in Ogun State. Int. J. Trop. Med. 2010, 5, 63-64.

19. Nwankwo, E.O.; Magaji, N.S.; Tijjani, J. Antibiotic susceptibility pattern of extended-spectrum $\beta$-lactamase (ESBL)-producers and other bacterial pathogens in Kano, Nigeria. Trop. Pharm. Res. 2015, 14, 1273-1278. [CrossRef]

20. Mashwal, F.A.; El Safi, S.H.; George, S.K.; Adam, A.A.; Jebakumar, A.Z. Incidence and molecular characterization of the extended spectrum $\beta$-lactamase-producing Escherichia coli isolated from urinary tract infections in Eastern Saudi Arabia. Saudi Med. J. 2017, 38, 811-815. [CrossRef]

21. Ouedraogo, A.S.; Sanou, M.; Kissou, A.; Sanou, S.; Solaré, H.; Kaboré, F.; Poda, A.; Aberkane, S.; Bouzinbi, N.; Sano, I.; et al. High prevalence of extended-spectrum B-lactamase producing enterobacteriaceae among clinical isolates in Burkina Faso. BMC Infect. Dis. 2016, 16, 326. [CrossRef]

22. Tellevik, M.S.; Blomberg, B.; Kommedal, Ø.; Maselle, S.Y.; Langeland, N.; Moyo, S.J. High prevalence of faecal carriage of ESBL-producing Enterobacteriaceae among children in Dar es Salaam, Tanzania. PLoS ONE 2016, 11, e0168024. [CrossRef]

23. Ahmed, S.F.; Ali, M.M.; Mohamed, Z.K.; Moussa, T.A.; Klena, J.D. Fecal carriage of extended-spectrum $\beta$-lactamase and AmpC-producing Escherichia coli in a Libyan community. Ann. Clin. Microb. 2014, 13, $22-27$. [CrossRef]

24. Blanc, V.; Leflon-Guibout, V.; Blanco, J.; Haenni, M.; Madec, J.Y.; Rafignon, G.; Bruno, P.; Mora, A.; Lopez, C.; Dahbi, G.; et al. Prevalence of day-care centre children (France) with faecal CTX-M-producing Escherichia coli comprising O256: H4 and O16: H5 STI31 strains. J. Antimicrob. Chemother. 2014, 69, 1231-1237. [CrossRef] [PubMed]

25. Fara, A.; Frank, T.; Tondeur, L.; Bata, P.; Gody, J.C.; Onambele, M.; Rafai, C.; Vray, M.; Breurec, S. High rate of faecal carriage of extended-spectrum $\beta$-lactamase-producing Enterobacteriaceae in healthy children in Bangui, Central African Republic. Clin. Microbiol. Infect. 2016, 22, 891-e1. [CrossRef] [PubMed]

26. Hijazi, S.M.; Fawzi, M.A.; Ali, F.M.; Abd El Galil, K.H. Prevalence and characterization of extended-spectrum $\beta$-lactamases producing Enterobacteriaceae in healthy children and associated risk factors. Ann. Clin. Microbiol. Anticrob. 2016, 15, 3. [CrossRef] [PubMed]

27. Stoesser, N.; Xayaheuang, S.; Vongsouvath, M.; Phommasone, K.; Elliott, I.; del Ojo Elias, C.; Crook, D.W.; Newton, P.N.; Buisson, Y.; Lee, S.J.; et al. Colonization with Enterobacteriaceae producing ESBLs in children in the Lao People's Democratic Republic. J. Antimicrob. Chemother. 2015, 70, 1837-1897.

28. Isendahl, J.; Turley-Rogacka, A.; Manjuba, C.; Rodrigues, A.; Giske, C.G.; Naucler, P. Fecal carriage of extended-spectrum $\beta$-lactamase-producing Escherichia coli and Klebsiella pneumoniae in children in Guinea-Bissau: A hospital-based cross-sectional study. PLoS ONE 2012, 7, e51981. [CrossRef] 
29. Woerther, P.L.; Angebault, C.; Jacquier, H.; Hugede, H.C.; Janssens, A.C.; Sayadi, S.; El Mniai, A.; Armand-Lefevre, L.; Ruppé, E.; Barbier, F.; et al. Massive increase, spread and exchange of extended spectrum $\beta$-lactamase-encoding genes among intestinal Enterobacteriaceae in hospitalized children with severe acute malnutrition in Niger. Clin. Infect. Dis. 2011, 53, 677-685. [CrossRef]

30. Yusha'u, M.M.; Aliyu, H.M.; Kumuya, A.S.; Suleiman, L. Prevalence of extended spectrum $\beta$-lactamases among Enterobacteriaceae in Murtala Muhammed Specialist Hospital, Kano, Nigeria. Bajopas 2010, 3, 69-77.

31. Yahaya, M.; Galadima, B.G.; Sambo, B.Z.; Aaron, O.A. Characterization of extended spectrum $\beta$-lactamase from Escherichia coli and Klebsiella species from North Eastern Nigeria. J. Clin. Diagn. Res. 2016, 10, 7-10.

32. Aibinu, I.E.; Ohaegbulam, V.C.; Adenipekun, E.A.; Ogunsola, F.T.; Odugbemi, T.O.; Mee, B.J. Extended-spectrum $\beta$-lactamase enzymes in clinical isolates of Enterobacter species from Lagos, Nigeria. J. Clin. Microbiol. 2003, 41, 2197-2000. [CrossRef]

33. Oli, A.N.; Eze, D.E.; Gugu, T.H.; Ezeobi, I.; Maduagwu, U.N.; Ihekwereme, C.P. Multi-antibiotic resistant extended-spectrum $\beta$-lactamase producing bacteria pose a challenge to the effective treatment of wound and skin infections. Pan Afr. Med. J. 2017, 27, 66. [CrossRef]

34. Chika, E.; Ifeanyichukwu, I.; Michael, A.; Charles, E. Susceptibility and detection of extended spectrum [ß]-lactamase enzymes from otitis media pathogens. Am. J. Infect. Dis. 2013, 9, 24-29. [CrossRef]

35. Pitout, J.D.; Laupland, K.B. Extended-spectrum $\beta$-lactamase-producing Enterobacteriaceae: An emerging public-health concern. Lancet Infect. Dis. 2008, 8, 159-166. [CrossRef]

36. Ejiofor, S.O.; Edeh, A.D.; Ezeudu, C.E.; Gugu, T.H.; Oli, A.N. Multi-Drug Resistant Acute Otitis Media amongst Children Attending Out-Patient Clinic in Chukwuemeka Odumegwu Ojukwu University Teaching Hospital, Awka, South-East Nigeria. Adv. Microbiol. 2016, 6, 495-501. [CrossRef]

37. Bialvaei, A.Z.; Samadi Kafil, H. Colistin, mechanisms and prevalence of resistance. Curr. Med. Res. Opin. 2015, 31, 707-721. [CrossRef] [PubMed]

38. Zheng, B.; Huang, C.; Xu, H.; Guo, L.; Zhang, J.; Wang, X.; Jiang, X.; Yu, X.; Jin, L.; Li, X.; et al. Occurrence and Genomic Characterization of ESBL-Producing, MCR-1-Harboring Escherichia coli in Farming Soil. Front. Microbiol. 2017, 8, 2510. [CrossRef]

39. Moawad, A.A.; Hotzel, H.; Neubauer, H.; Ehricht, R.; Monecke, S.; Tomaso, H.; Hafez, H.M.; Roesler, U.; El-Adawy, H. Antimicrobial resistance in Enterobacteriaceae from healthy broilers in Egypt: Emergence of colistin-resistant and extended-spectrum $\beta$-lactamase-producing Escherichia coli. Gut Pathog. 2018, 10, 39. [CrossRef]

40. Pishnian, Z.; Haeili, M.; Feizi, A. Prevalence and molecular determinants of colistin resistance among commensal Enterobacteriaceae isolated from poultry in northwest of Iran. Gut Pathog. 2019, 11, 2. [CrossRef]

41. Dandachi, I.; Chabou, S.; Daoud, Z.; Rolain, J.M. Prevalence and Emergence of Extended-Spectrum Cephalosporin-, Carbapenem- and Colistin-Resistant Gram-Negative Bacteria of Animal Origin in the Mediterranean Basin. Front. Microbiol. 2018, 9, 2299. [CrossRef]

42. Zurfuh, K.; Poirel, L.; Nordmann, P.; Nüesch-Inderbinen, M.; Hächler, H.; Stephan, R. Occurrence of the Plasmid-Borne mcr-1 Colistin Resistance Gene in Extended-Spectrum- $\beta$-Lactamase-Producing Enterobacteriaceae in River Water and Imported Vegetable Samples in Switzerland. Antimicrob. Agents Chemother. 2016, 60, 2594-2595. [CrossRef]

43. Nakayama, T.; Kumeda, Y.; Kawahara, R.; Yamaguchi, T.; Yamamoto, Y. Carriage of colistin-resistant, extended-spectrum $\beta$-lactamase-producing Escherichia coli harboring the $\mathrm{mcr}$ - 1 resistance gene after short-term international travel to Vietnam. Infect. Drug Resist. 2018, 11, 391-395. [CrossRef]

44. Mariappan, S.; Sekar, U.; Kamalanathan, A. Carbapenemase-producing Enterobacteriaceae: Risk factors for infection and impact of resistance on outcomes. Int. J. Appl. Basic Med. Res. 2017, 7, 32-39. [CrossRef] [PubMed]

45. Oli, A.N.; Itumo, C.J.; Okam, P.C.; Ezebialu, I.U.; Okeke, K.N.; Ifezulike, C.C.; Ezeobi, I.; Emechebe, G.O.; Okezie, U.M.; Adejumo, S.A.; et al. Carbapenem-Resistant Enterobacteriaceae Posing a Dilemma in Effective Healthcare Delivery. Antibiotics 2019, 8, 156. [CrossRef] [PubMed]

46. Oli, A.N. How much Immunogenic are the Oral Polio Vaccines Sourced from the Central Cold-chain Facilities in South-Eastern Nigeria? J. Basic Clin. Pharma 2017, 8, S111-S115. 
47. Pollard, A.J. Childhood immunisation: What is the future? Arch. Dis. Child. 2007, 92, 426-433. [CrossRef]

48. Oli, A.N.; Akabueze, V.B.; Ezeudu, C.E.; Eleje, G.U.; Ejiofor, O.S.; Ezebialu, I.U.; Oguejiofor, C.B.; Ekejindu, I.M.; Emechebe, G.O.; Okeke, K.N. Bacteriology and antibiogram of urinary tract infection among female patients in a tertiary health facility in south eastern nigeria. Open Microbiol. J. 2017, 11, 292-300. [CrossRef]

(C) 2019 by the authors. Licensee MDPI, Basel, Switzerland. This article is an open access article distributed under the terms and conditions of the Creative Commons Attribution (CC BY) license (http://creativecommons.org/licenses/by/4.0/). 